\title{
Synergistic protective role of ceftriaxone and ascorbic acid against subacute diazinon-induced nephrotoxicity in rats
}

\author{
Mohamed M. Abdel-Daim
}

Received: 1 April 2014/Accepted: 31 July 2014/Published online: 24 August 2014

(C) Springer Science+Business Media Dordrecht 2014

\begin{abstract}
Diazinon (DZN) is a synthetic organophosphrus acaricide and insecticide widely used for veterinary and agricultural purposes. However, its animal and human exposure leads to nephrotoxicity. Our experimental objective was to evaluate protective effects of ceftriaxone and/or ascorbic acid-vitamin C against DZN-induced renal injury in male Wistar albino rats. DZN-treated animals revealed significant elevation in serum biochemical parameters related to renal injury: urea, uric acid and creatinine. DZN intoxication significantly increased renal lipid peroxidation, and significant inhibition in antioxidant biomarkers including, reduced glutathione, glutathione peroxidase, superoxide dismutase, catalase and total antioxidant capacity. In addition, DZN significantly reduced serum acetylcholinestrase level. Moreover, It induced serum and kidney tumor necrosis factor- $\alpha$ level. Both ceftriaxone and vitamin $\mathrm{C}$ protect against DZN-induced serum as well as renal tissue biochemical parameters when used alone or in combination along with DZN-intoxication. Furthermore, both ceftriaxone and vitamin $\mathrm{C}$ produced synergetic nephroprotective and antioxidant effects. Therefore, it could be concluded that ceftriaxone and/or vitamin $\mathrm{C}$ administration are able to minimize the toxic effects
\end{abstract}

M. M. Abdel-Daim ( $\bowtie)$

Pharmacology Department, Faculty of Veterinary

Medicine, Suez Canal University, Ismailia 41522, Egypt

e-mail: abdeldaim.m@vet.suez.edu.eg;

abdeldaim.m@gmail.com of DZN by its free radical-scavenging and potent antioxidant activity.

Keywords Diazinon - Nephrotoxicity - Ceftriaxone Vitamin C $\cdot$ Antioxidant $\cdot$ Kidney $\cdot$ Rats

\section{Introduction}

Pesticides are used extensively throughout the world for control of agricultural, veterinary and domestic insect pests and disease vectors in order to enhance the food production and maintain human and animal health. The wide-spread use of pesticides in agricultural programs and public health has caused serious ecological problems and potential health hazards, including severe acute, subacute and chronic cases of poisonings of humans and animals and therefore, are main reasons of concern (Ranjbar et al. 2002; AbdelDaim and Halawa 2014; Abdel-Daim et al. 2014).

Among pesticides are organophosphorous insecticide, which have fully replaced the chlorinated hydrocarbons since 4 decades. The main advantage of the organophosphorous compounds is their shortterm persistence in the ecosystem and low cumulative action (Zavon 1971). Although the organophosphates have been replaced by pyrethroid pesticides within the last 10-15 years, there is still a very intensive use of the organophosphorus insecticides (Salem and Olajos 1988). 
Diazinon [phosphoric acid, $O, O$-diethyl $O$-(2-isopropyl-6-methyl-4-pyridinyl)] phosphorothioate is an organophosphorus insecticide used worldwide in veterinary, agricultural, and domestic practice to control ticks, fleas, lice, flies, and other insect pests of domestic animals, ornamental plants, and food crops (Larkin and Tjeerdema 2000). Toxic effects of DZN on target and non-target organisms are mainly due to the inhibition of acetylcholinesterase (AChE) activity, which is a crucial enzyme for normal nervous tissue physiology. DZN induces its toxicity by binding its oxygen analog to the neuronal enzyme AChE, leading to accumulation of the endogenous neurotransmitter; acetylcholine in neurons and effectors organ (Larkin and Tjeerdema 2000). Moreover, it disrupts mitochondrial membrane transport in rat liver and affects cytochrome P450 system in human liver (Sams et al. 2004). Furthermore, DZN toxicity induced oxidative damage resulting in hematological disorders, cardiotoxicity, hepatotoxicity, nephrotoxicity, neurotoxicity, and both female and male reproductive toxicity (AlAttar and Abu Zeid 2013; Razavi et al. 2013; Elmazoudy et al. 2011; ElMazoudy and Attia 2012).

The cells overcome oxidative stress by either removal of the damaged nucleotides and products of the lipid peroxidation or directly scavenging free radicals via endogenous enzymatic and non-enzymatic antioxidants (Madkour and Abdel-Daim 2013; Abdel-Daim et al. 2013; Azab et al. 2013).

Ceftriaxone (CTX) is a broad-spectrum antimicrobial cephalosporin, resistant to beta-lactamases, with potent activities against gram-negative and grampositive microorganisms (Neu et al. 1981). It is effective against Streptococcus pyogenes, Streptococcus feacalis, Streptococcus pneumonia, Haemophilus influenza, Brucella melitensis, and Neisseria gonorrhoeae (Neu et al. 1981). CTX acts by inhibition of transpeptidase enzymes which are responsible for the final step in bacterial cell wall synthesis and has significant stability against beta-hydrolysis (Neu 1985). Other non-antibiotic actions of CTX on animal studies demonstrated that it could ameliorate morphine tolerance (Rawls et al. 2010b), and dependence (Rawls et al. 2010a), diabetic hyperalgesia (Gunduz et al. 2011) and neuropathic pain (Liu et al. 2010). Moreover, CTX attenuate cyclosporine A (Yilmaz et al. 2011), tobramycin (Beauchamp et al. 1994), isepamicin (Yoshiyama et al. 1998), and cadmiuminduced (Dwivedi et al. 2012) nephrotoxicity in rats.
Ascorbic acid (AA) — vitamin C - is probably the most crucial antioxidant in extracellular fluids. It is an important vitamin and an essential component in the diet of many mammalian species. It is highly water soluble and acts as an efficient reducing agent. AA is the most effective antioxidant in preventing lipid peroxidation initiated by peroxyl radicals, and considered as a potent free radical scavenger (El-Demerdash et al. 2005; Kojo 2004). Moreover, it may restore other antioxidants such as vitamin E (Carr and Frei 1999). To our knowledge, the role of CTX and AA, alone or in combination against DZN-induced biochemical alteration of serum as well as renal lipid peroxidation and antioxidant status in rats has not been studied yet. Therefore, the present study was designed to investigate the alterations in serum biochemical parameters related renal damage as well as renal lipid peroxidation and oxidative stress induced by DZN in rats. Moreover, the role of ceftriaxone and/or vitamin $\mathrm{C}$ supplementation in alleviating these DZN-induced hazard effects could be evaluated.

\section{Materials and methods}

\section{Chemicals}

Diazinon (DZN); Diazinon ${ }^{\circledR} 60$ a commercial emulsifiable formulation containing $60 \%$ active ingredient, was purchased from Adwia Pharmaceuticals (Cairo, Egypt). DZN was diluted in deionized water for the final required concentration. Ceftriaxone (CTX) (Ceftriaxone ${ }^{\circledR}$ vial, $250 \mathrm{mg}, 500 \mathrm{mg}$ and $1 \mathrm{~g}$ crystalline powder) was kindly given by SandozNovartis, Egypt. Ascorbic acid was purchased from Adwia Pharmaceuticals (Cairo, Egypt). All kits were purchased from Biodiagnostics Cairo, Egypt except, AChE, from (BioVision Inc., Milpitas, CA, USA) and TNF- $\alpha$ from Assay Designs Inc. (Ann Arbor, MI, USA). All other chemicals used in the experiment were of analytical grade.

Animals and experimental design

Fifty-six male Wistar rats, weighing $175 \pm 25 \mathrm{~g}$, were bought from The Egyptian Organization for Biological Products and Vaccines (Giza, Egypt). Rats were kept in a ventilated animal house of normal light-dark cycle (12 h light/dark) and temperature $\left(25 \pm 2{ }^{\circ} \mathrm{C}\right)$. 
Table 1 Summary of different rat groups and their treatment

\begin{tabular}{llcl}
\hline Group & DZN & CTX & AA \\
\hline Control & - & - & - \\
CTX & - & + & - \\
AA & - & - & + \\
DZN & + & - & - \\
DZN-CTX & + & + & - \\
DZN-AA & + & - & + \\
DZN-CTX-AA & + & + & + \\
\hline
\end{tabular}

Diazinon $20 \mathrm{mg} / \mathrm{kg}$ body weight, daily for 4 weeks (DZN), Ceftriaxone at $100 \mathrm{mg} / \mathrm{kg}$ body weight daily for 4 weeks, $1 \mathrm{~h}$ before DZN dose (CTX), Ascorbic acid (vitamin C) $100 \mathrm{mg} /$ $\mathrm{Kg}$ body weight daily, $1 \mathrm{~h}$ before DZN administration (AA)

Food and water were provided ad libitum. Experimental design and all animal handling procedures were approved by the Research Ethical Committee of the Faculty of Veterinary Medicine, Suez Canal University, Ismailia, Egypt (approval no. 20147). All precautions were taken into consideration to avoid animal stress.

Rats were kept for 1 week before the beginning of the experiment for acclimatization. Next, rats were randomly divided into seven different groups; 8 animals in each. Rats in the 1st group were administered normal saline and kept as control. The 2nd and 3 rd groups were given CTX (100 mg/kg bw SC) (Amin et al. 2012) and ascorbic acid $(100 \mathrm{mg} / \mathrm{kg}$ bw orally) (Li et al. 2010) daily for 4 weeks. The 4 th group received a daily dose of DZN (20 mg/kg, SC) (Hariri et al. 2010). The 5th and 6th groups were given CTX and AA at the same dose regimen used for the 2nd and 3rd groups before DZN administration at the same dose and regimen used for the 4 th group. The 7th group was given both CTX and AA $1 \mathrm{~h}$ before DZN administration (Table 1).

Serum collection and tissue preparation

At the end of the experiment ( $24 \mathrm{~h}$ after the DZN dose), blood samples were collected via retro-orbital plexus under light ether anaesthesia. Blood samples were left to clot at room temperature and centrifuged at 3,000 rpm for $15 \mathrm{~min}$. Sera were then, separated and stored at $-20{ }^{\circ} \mathrm{C}$ as aliquots for further biochemical analysis.

After blood collection, rats were sacrificed by cervical decapitation. Kidneys were rapidly excised from each animal, trimmed of connecting tissue, and washed with $0.9 \% \mathrm{NaCl}$ solution and distilled water for removal of the blood. Next kidneys were blotted over a piece of filter paper and perfused with a $50 \mathrm{mM}$ (sodium phosphate buffer saline (100 mM Na $\left.2 \mathrm{HPO}_{4} / \mathrm{NaH}_{2} \mathrm{PO}_{4}\right)$ $(\mathrm{pH}$ 7.4) in an ice-containing medium, containing 0.1 $\mathrm{mM}$ ethylene-di-amine-tetra-acetic-acid (EDTA) to remove any clots and blood cells. Subsequently, renal tissues were homogenized in 5-10 $\mathrm{ml}$ cold buffer per gram tissue and centrifuged at 5,000 rpm for $30 \mathrm{~min}$. The resulting supernatant was then transferred into Eppendorf tubes, and kept at $-80{ }^{\circ} \mathrm{C}$ in a deep freezer until used for various biochemical Assays.

Serum biochemical analysis

The sera stored at $-20{ }^{\circ} \mathrm{C}$ were used for estimation of serum renal injury marker products; creatinine, urea and uric acid were determined according to Larsen (1972), Coulombe and Favreau (1963) and Whitehead et al. (1991), respectively. Acetylcholinesterase (AChE) was measured according to Ellman et al. (1961).

Evaluation of tissue lipid peroxidation and antioxidant enzymes

Lipid peroxidation was evaluated by measurement of MDA content in renal tissues according to Mihara and Uchiyama (1978). Serum nitric oxide (NO) xere determined according to Green et al. (1982). The non-enzymatic antioxidant biomarker; reduced glutathione (GSH) was assessed according to Beutler et al. (1963). The enzymatic antioxidant biomarkers; superoxide dismutase (SOD) was evaluated according to Nishikimi et al. (1972), glutathione peroxidase (GSHPx) according to Paglia and Valentine (1967) and catalase (CAT) according to Aebi (1984). In addition, total antioxidant capacity (TAC) was determined according to Koracevic et al. (2001).

\section{Serum and kidney TNF- $\alpha$ assays}

Serum and renal tissue TNF- $\alpha$ levels were measured using coomercial kits from R\&D Systems (Minneapolis, MN, USA) according to the manufacturer's protocol. Briefly, in a microplate, $50 \mu \mathrm{l}$ of the assay diluent was added to each well. Then, $50 \mu \mathrm{l}$ of the diluted serum or renal tissue homogenate supernatant samples were added to each well and gently mixed by tapping the plate frame for $1 \mathrm{~min}$ then the plate was 
Fig. 1 Serum urea levels in the control and the different treated groups. Different letters mean statistical significance at $P \leq 0.05$ according to one-way ANOVA followed by Tukey's Range Test for post hoc analysis

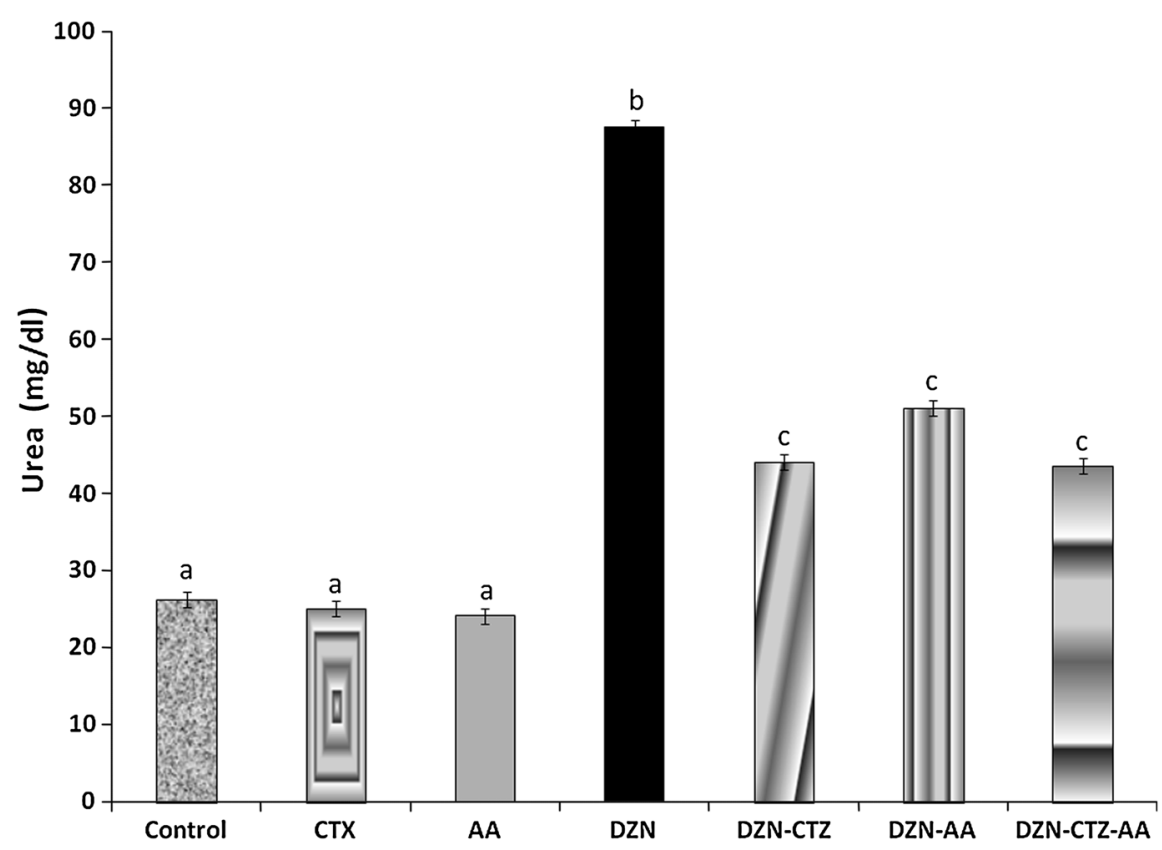

covered and incubated at room temperature for $2 \mathrm{~h}$. After incubation, each well in the plate was then aspirated and washed five times with the kit washing buffer, then $100 \mu \mathrm{l}$ substrate solutions were added and incubated at room temperature in the dark for $30 \mathrm{~min}$. The optical density was then read at $450 \mathrm{~nm}$ using 96-well microtiter plates ELISA reader. TNF- $\alpha$ level was calculated from a standard curve and multiplied by the dilution factor.

\section{Statistical analysis}

Data are presented as mean \pm SE. Statistical significance of the data was analyzed using SPSS programme (Statical package for Social Science) version 16. For comparison, one-way analysis of variance (ANOVA) test and post-comparison was carried out with Tukey's Range Test for post hoc analysis. Statistical significance was acceptable at a level of $P \leq 0.05$.

\section{Results}

Serum biochemical analysis

The effects of DZN intoxication as well as the preventive effects of CTX and/or AA on serum biochemical analyses are shown in Figs. 1-4. Significant increases $(P \leq 0.05)$ in serum renal injury markers (urea, uric acid and creatinine) were recorded in DZN intoxicated rats as compared to the untreated control group (333.68 \%, $328.85 \%$ and 2,412. $30 \%$, respectively) (Figs. 1, 2, 3, respectively). On another hand, AChE was significantly $(P \leq 0.05)$ decreased in DZN intoxicated rats $(55.19 \%)$ compared to the control rats (Fig. 4).

Pre-treatment with CTX at doses of $100 \mathrm{mg} / \mathrm{kg}$ significantly $(P \leq 0.05)$ reduced the serum renal injury markers: urea, uric acid and creatinine (about 58.33, 54.37 and $32.70 \%$, respectively), while AA pre-treatment at a dose of $100 \mathrm{mg} / \mathrm{kg}$ significantly $(P \leq 0.05)$ reduced these biomarkers (about 49.67, 48.67 and $30.02 \%$, respectively) compared with the DZN-intoxicated group. Moreover, both CTX and AA were given in combination and significantly $(P \leq 0.05)$ reduced the same parameters more than when each of them were used alone (about 29.65, 31.87 and $7.15 \%$, respectively) (Figs. 1, 2, 3, respectively). At the same time, pretreatment with CTX, AA or both in combination significantly $(P \leq 0.05)$ increased serum AChE level (143.71, 152.83 and $179.64 \%$, respectively) compared with the DZN-intoxicated rats (Fig. 4).

There were no significant changes in serum markers in rats having received CTX or AA only at a dose of $100 \mathrm{mg} / \mathrm{kg}$ (2nd and 3rd groups, respectively) if compared to the normal control (1st group), indicating the safety of CTX and AA at the selected doses used in this study (Figs. 1-4). 
Fig. 2 Serum uric acid levels in the control and the different treated groups. Different letters mean statistical significance at $P \leq 0.05$ according to oneway ANOVA followed by Tukey's Range Test for post hoc analysis

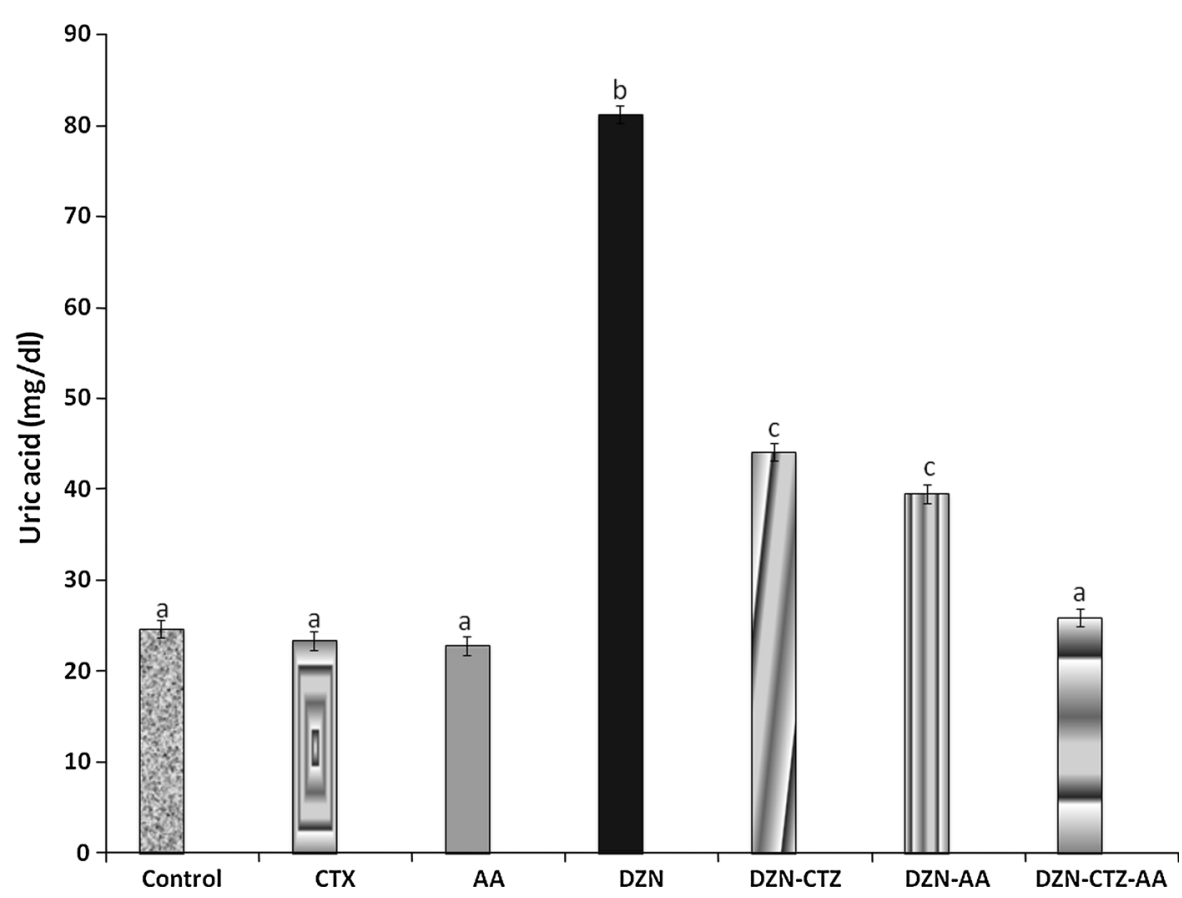

Fig. 3 Serum creatinine levels in the control and the different treated groups. Different letters mean statistical significance at $P \leq 0.05$ according to oneway ANOVA followed by Tukey's Range Test for post hoc analysis

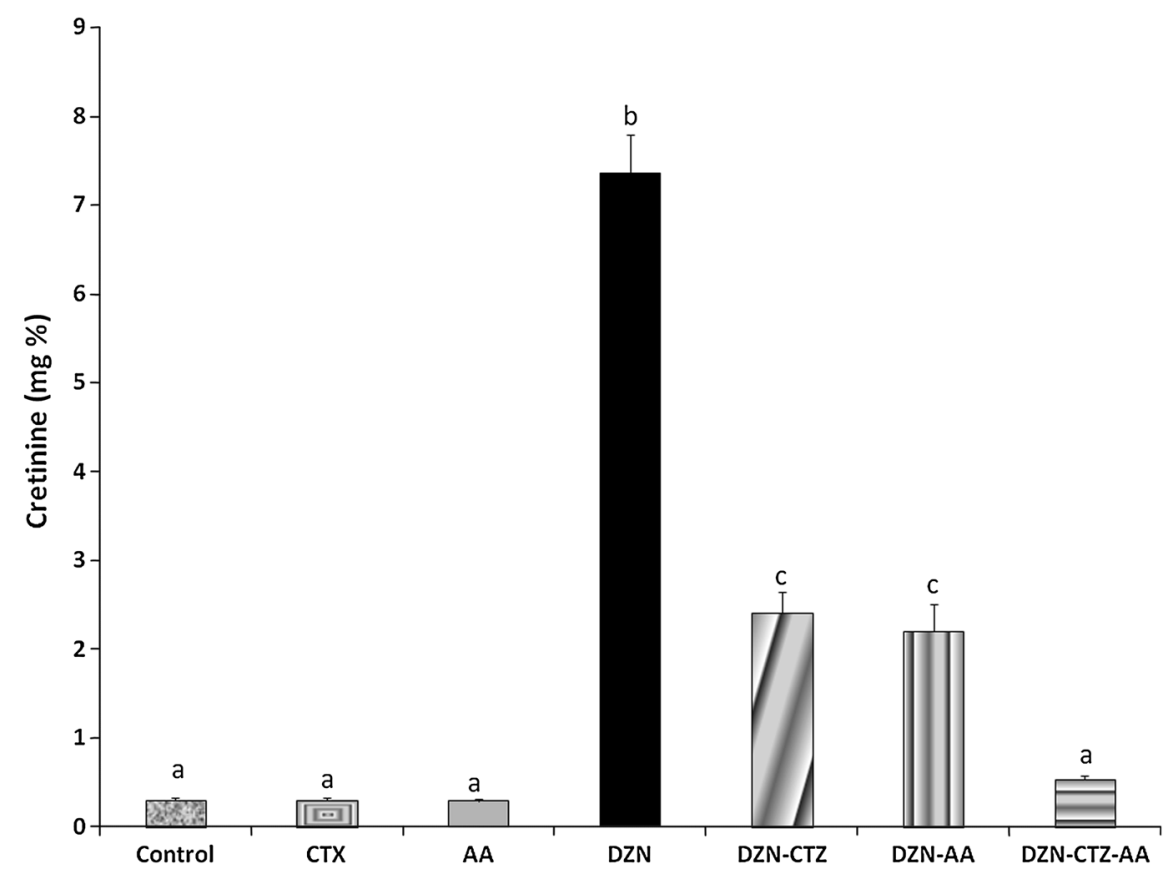

Renal lipid peroxidation and antioxidant biomarkers

The effects of DZN intoxication as well as preventive effects of CTX and/or AA on renal tissue homogenate lipid peroxidation and antioxidant parameters are shown in Table 2. A significant increase $(P \leq 0.05)$ in renal MDA and NO content (447.56 and $257.65 \%$, respectively) was observed compared to the control group. On the other hand, renal GSH, GSH-Px, SOD, 
Fig. 4 Serum AChE levels in the control and the different treated groups. Different letters mean statistical significance at $P \leq 0.05$ according to oneway ANOVA followed by Tukey's Range Test for post hoc analysis

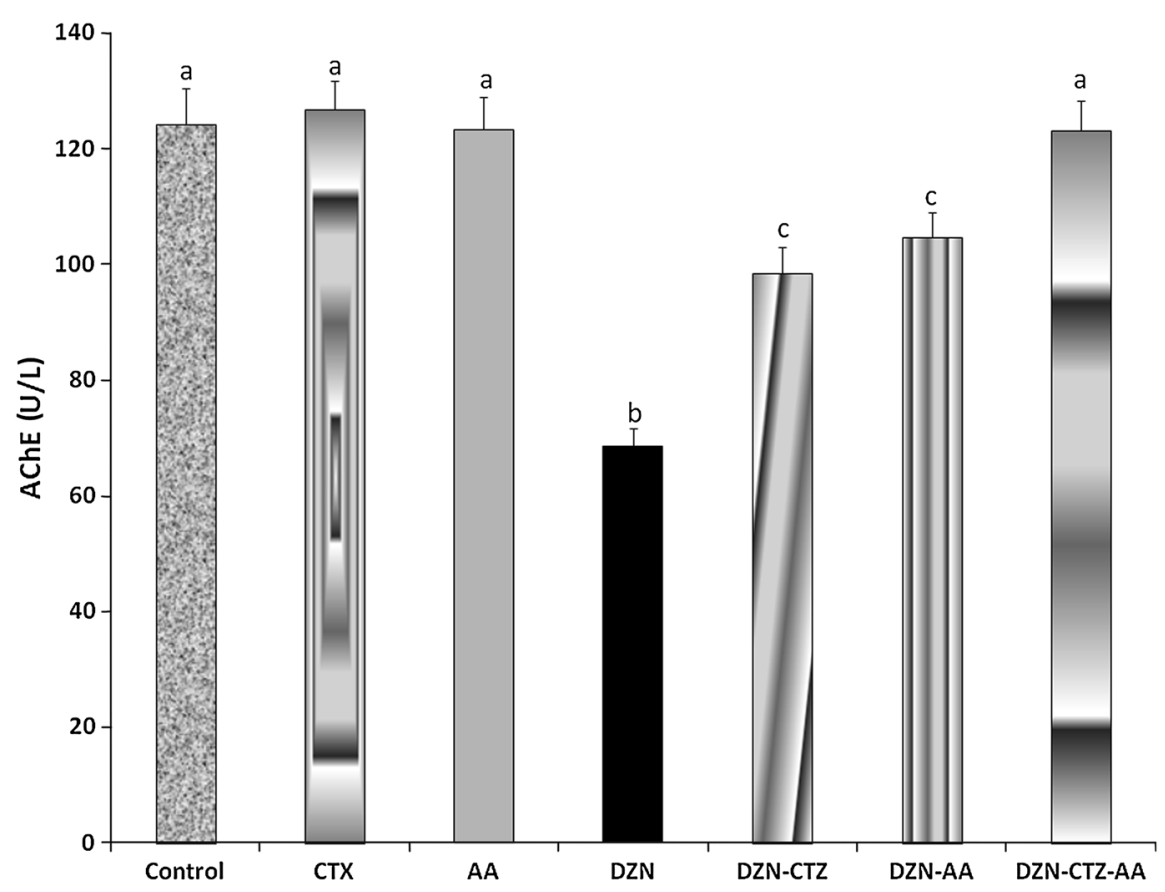

CAT and TAC were significantly $(P \leq 0.05)$ decreased (59.06, 43.10, 38.81, 48.62 and $71.25 \%$, respectively). Concerning DZN-CTX group, renal MDA and NO were decreased (73.31 and $68.46 \%$, respectively) while GSH, GSH-Px, SOD, CAT, and TAC were increased (139.21, 171.51, 185.22,139.84 and $118.16 \%$, respectively) compared to the DZNintoxicated group. Regarding to DZN-AA group, renal MDA and NO were decreased (45.62 and $63.87 \%$, respectively), while GHS, GSH-Px, SOD, CAT, and TAC were increased (about 154.83, 207.26, 213.34, 173.98 and $133.67 \%$, respectively). In addition, both CTX and AA were given in combination, significantly $(P \leq 0.05)$ reduced renal MDA and NO level (26.20 and $43.67 \%$, respectively) and increased GHS, GSHPx, SOD, CAT, and TAC more than when each of them was used alone (about 172.94, 234.44, 271.06, 208.13 and $147.79 \%$, respectively) (Table 2 ).

Serum and kidney TNF- $\alpha$ assays

DZN intoxication significantly $(P \leq 0.05)$ increased both serum and renal tissue TNF- $\alpha$ (566.88 and $801.24 \%$, respectively) compared with the control rats (Figs. 5, 6). Pretreatment with CTX significantly $(P \leq 0.05)$ reduced both serum and renal TNF- $\alpha$ levels (43.42 and $39.83 \%$, respectively), at the same time AA pretreatment induced significantly $(P \leq 0.05)$ reduction of both levels (about 37.47 and $33.49 \%$, respectively). Moreover, when both CTX and AA were given in combination they induced a more significant $(P \leq 0.05)$ reduction in these levels (21.81 and $15.49 \%$, respectively) compared to the DZN-intoxicated rats (Figs. 5, 6).

\section{Discussion}

Reactive oxygen species (ROS) are continuously generated inside the mammalian body as a result of exposure to many exogenous chemicals, xenobiotics and drugs in our environment and/or endogenous metabolic events involving electron transport mechanism and redox enzymes (Al-Sayed et al. 2014; Eldahshan and Abdel-Daim 2014; Abdel-Daim 2014). In normal conditions, there is balance between the ROS produced and the antioxidants, as the ROS generated are neutralized by the endogenous antioxidants (Sun 1990). Deleterious effects caused by ROS occur as a result of an imbalance between the formation and inactivation of these agents leading to disturbance in normal cellular physiology and different pathological conditions (Sun 1990; Ibrahim and Abdel Daim 2015). Free radicals have been implicated in the pathogenesis of many 
Table 2 Renal tissue malondialdhyde, nitric oxide and antioxidant biomarkers in the control and the different treated groups

\begin{tabular}{|c|c|c|c|c|c|c|c|}
\hline \multirow[t]{2}{*}{ Parameters } & \multicolumn{7}{|c|}{ Experimental groups } \\
\hline & Control & CTX & AA & $\mathrm{DZN}$ & DZN-CTX & DZN-AA & $\begin{array}{l}\text { DZN-CTX- } \\
\text { AA }\end{array}$ \\
\hline $\begin{array}{l}\text { MDA (nmol/ } \\
\mathrm{g})\end{array}$ & $3.43^{\mathrm{a}} \pm 0.19$ & $3.34^{\mathrm{a}} \pm 0.17$ & $3.30^{\mathrm{a}} \pm 0.19$ & $16.25^{\mathrm{b}} \pm 1.27$ & $11.92^{\mathrm{c}} \pm 0.45$ & $7.42^{\mathrm{d}} \pm 0.52$ & $4.26^{\mathrm{a}} \pm 0.21$ \\
\hline $\mathrm{NO}(\mu \mathrm{mol} / \mathrm{g})$ & $6.52^{\mathrm{a}} \pm 0.40$ & $6.37^{\mathrm{a}} \pm 0.35$ & $6.27^{\mathrm{a}} \pm 0.43$ & $16.81^{\mathrm{b}} \pm 1.07$ & $11.51^{\mathrm{c}} \pm 0.61$ & $10.74^{\mathrm{c}} \pm 0.76$ & $7.34^{\mathrm{a}} \pm 0.36$ \\
\hline GSH (mg/g) & $7.07^{\mathrm{a}} \pm 0.32$ & $7.27^{\mathrm{a}} \pm 0.37$ & $7.64^{\mathrm{a}} \pm 0.36$ & $4.18^{\mathrm{b}} \pm 0.14$ & $5.81^{\mathrm{c}} \pm 0.28$ & $6.47^{\mathrm{ac}} \pm 0.21$ & $7.22^{\mathrm{a}} \pm 0.29$ \\
\hline $\begin{array}{l}\text { GSH-Px (mg/ } \\
\text { g) }\end{array}$ & $4.88^{\mathrm{a}} \pm 0.30$ & $5.10^{\mathrm{a}} \pm 0.36$ & $5.51^{\mathrm{a}} \pm 0.24$ & $2.10^{\mathrm{b}} \pm 0.17$ & $3.60^{c} \pm 0.24$ & $4.36^{\mathrm{ac}} \pm 0.28$ & $4.93^{\mathrm{a}} \pm 0.27$ \\
\hline SOD (U/g) & $18.33^{\mathrm{a}} \pm 1.47$ & $18.74^{\mathrm{a}} \pm 1.49$ & $19.55^{\mathrm{a}} \pm 1.35$ & $7.11^{b} \pm 0.45$ & $13.18^{\mathrm{c}} \pm 0.64$ & $15.18^{\mathrm{ac}} \pm 0.80$ & $19.28^{\mathrm{a}} \pm 0.92$ \\
\hline CAT (U/g) & $0.32^{\mathrm{a}} \pm 0.03$ & $0.33^{\mathrm{a}} \pm 0.02$ & $0.35^{\mathrm{a}} \pm 0.02$ & $0.15^{\mathrm{b}} \pm 0.01$ & $0.22^{\mathrm{c}} \pm 0.01$ & $0.27^{\mathrm{ac}} \pm 0.01$ & $0.32^{\mathrm{a}} \pm 0.02$ \\
\hline $\begin{array}{l}\text { TAC ( } \mu \mathrm{mol} / \\
\mathrm{g})\end{array}$ & $1.39^{\mathrm{a}} \pm 0.05$ & $1.45^{\mathrm{a}} \pm 0.06$ & $1.49^{\mathrm{a}} \pm 0.07$ & $0.99^{\mathrm{b}} \pm 0.05$ & $1.17^{\mathrm{c}} \pm 0.04$ & $1.33^{\mathrm{a}} \pm 0.05$ & $1.47^{\mathrm{a}} \pm 0.04$ \\
\hline
\end{tabular}

Data are expressed as mean $\pm \mathrm{SE} ;(n=8) . D Z N$ Diazinon, $C T X$ ceftriaxone, $A A$ ascorbic acid, $M D A$ malondialdehyde, $N O$ nitric oxide, $G S H$ reduced glutathione, $S O D$ superoxide dismutase, $C A T$ catalase, TAC total antioxidant capacity. Within the same row, different letters mean statistical significance at $(P \leq 0.05)$ according to one-way ANOVA followed by Tukey's Range Test for post hoc analysis

Fig. 5 Serum TNF- $\alpha$ levels in the control and the different treated groups. Different letters mean statistical significance at $P \leq 0.05$ according to oneway ANOVA followed by Tukey's Range Test for post hoc analysis

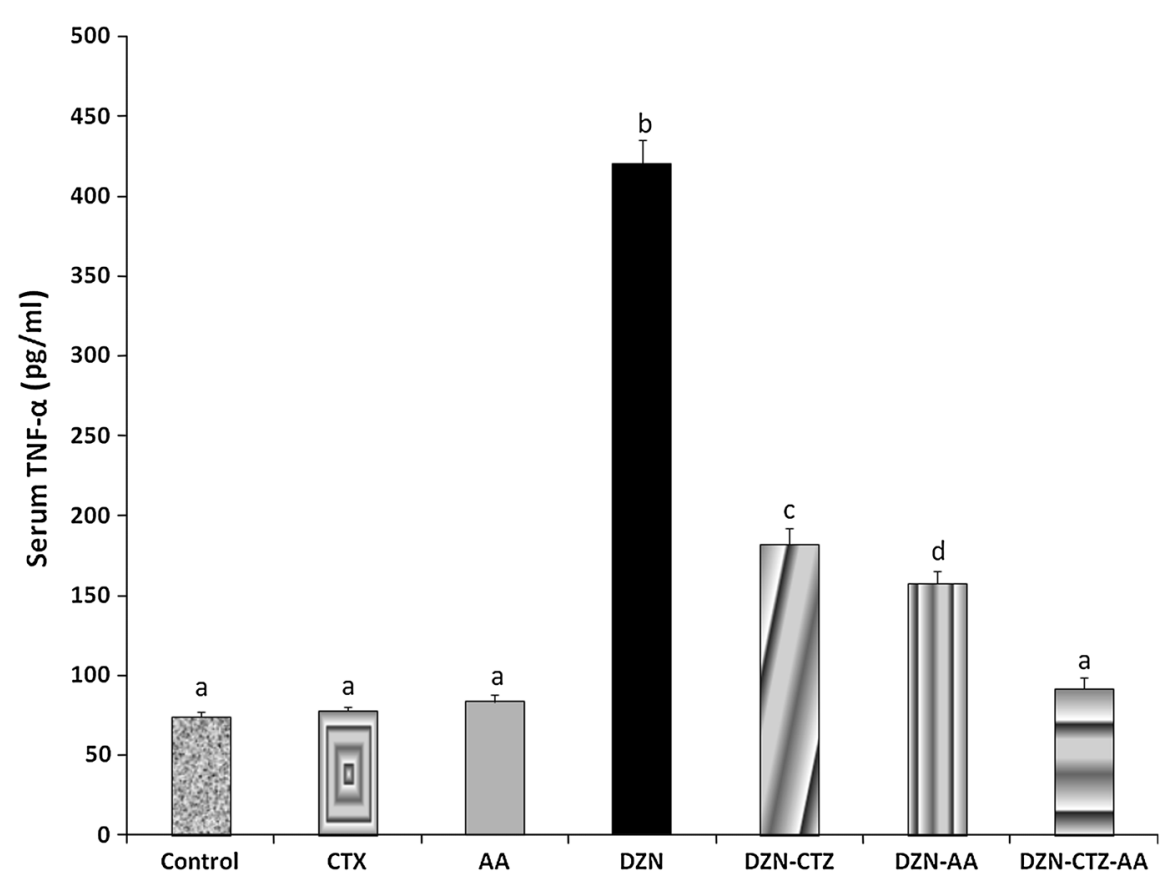

animals and human as well (Larkin and Tjeerdema 2000). Although several investigations about DZN toxicity have been published, little study has been performed about the preventive agents used against such a toxicity and mechanism of their ameliorative action (Larkin and Tjeerdema 2000; Al-Attar and Abu Zeid 2013; Razavi et al. 2013; Elmazoudy et al. 2011; ElMazoudy and Attia 2012). 
Fig. 6 Renal TNF- $\alpha$ levels in the control and the different treated groups. Different letters mean statistical significance at $P \leq 0.05$ according to oneway ANOVA followed by Tukey's Range Test for post hoc analysis

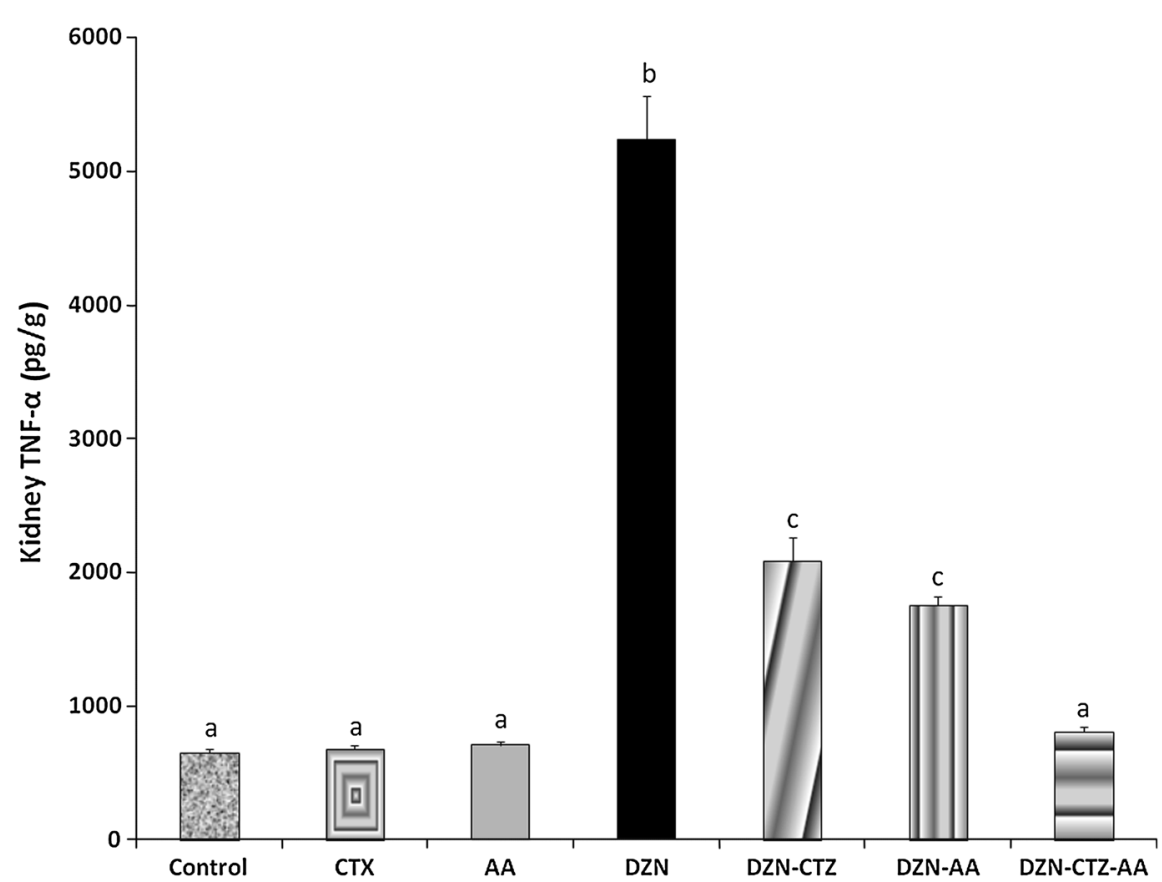

In the present study, the renal injuries caused by DZN may be caused by the oxidative stress resulted from free radical production. DZN intoxication significantly $(P \leq 0.05)$ increased serum renal injury markers: urea, uric acid and creatinine. Moreover, it significantly $(P \leq 0.05)$ reduced serum AchE level (Figs. 1-4). DZN treatment significantly $(P \leq 0.05)$ increased lipid peroxidation through elevated kidney MDA level, significantly ( $P \leq 0.05$ ) decreased kidney enzymatic; GSH-Px, SOD and CAT as well as nonenzymatic; GSH antioxidant level (Table 2). In addition, it significantly $(P \leq 0.05)$ increased both serum and renal tissue TNF- $\alpha$ compared with the control group.

All these effects are involved in the cascade of events leading to DZN-mediated kidney oxidative stress and toxicity. This indicates that renal injuries induced by DZN is the result from oxidative stress that arises as a result of excessive ROS production, which have been known to attack various cellular molecules, including lipids and causing lipid peroxidation. The activities of antioxidant enzymes, including the enzymes involved in glutathione metabolism were also disrupted in the DZN-intoxicated group (Table 2) indicating the involvement of oxidative stress in DZNmediated renal damage. These results are consistent with the literature and point towards the role of ROS in DZN-mediated injury and toxicity. The insecticide, diazinon was reported to increase serum urea and creatinine, urinary glucose, and renal tissue MDA, while antioxidant markers were decreased in rats and mice (Boroushaki et al. 2013; Cakici and Akat 2013; El-Demerdash and Nasr 2013). Long term administration of diazinon in rabbits induced significant oxidative DNA damage in the liver and kidney and significantly reduced plasma CAT, GSH and TAC levels (Tsitsimpikou et al. 2013). The levels of serum TNF- $\alpha$, uric acid, LDH, AST, ALT were significantly increased by sub-acute administration of diazinon in rats (Hariri et al. 2010).

In the current study, the pre-administration of CTX and/or AA at a dose level of $100 \mathrm{mg} / \mathrm{kg}$ for each, reduced the serum renal injury markers. Moreover, they reduced the lipid peroxidation in kidney tissues. In addition, there were elevations of renal antioxidant enzymes and glutathione levels due to the administration of both preventive agents. Furthermore, they increased serum AChE and reduced serum and kidney TNF- $\alpha$. Both CTX and vitamin C induced synergistic protective effects against DZN-induced biochemical alterations of serum and tissues (Table 2; Figs. 1-6).

These results are in agreement with many previous literatures, which examined the nephroprotective and antioxidant effects of CTX against many drugs and xenobiotics-induced nephrotoxicity (Yilmaz et al. 2011; Beauchamp et al. 1994; Yoshiyama et al. 
1998; Dwivedi et al. 2012). Pre-treatment with AA might play a role in reducing the toxic effect of DZN, and its powerful antioxidant properties seem to mediate such a protective effect, indicated by the reduction of MDA as well as the elevation of GSH, GSH-Px, SOD, CAT and TAC levels in renal tissue (Nematbakhsh et al. 2012; Ashrafi et al. 2012; Rehman et al. 2012; Saleem et al. 2012).

The protective effect of CTX and/or vitamin C against DZN-induced oxidative stress in our rat model could be either directly by scavenging ROS and inhibition of lipid peroxidation and/or indirectly through the enhancement of the activities of SOD and CAT, the enzymatic free radicals' scavengers in the cells. Therefore, CTX and vitamin C could be used in combination to prevent and treat renal diseases, especially those induced by oxidative damage.

\section{Conclusion}

Oxidative stress plays a major role in DZN-induced nephrotoxicity. Antioxidants have been proven to be effective in preventing DZN-induced toxicity in many previous interventions. CTX and AA are potent antioxidants, which are reported to ameliorate the effect of many known nephrotoxic agents.

In the present study, clearly DZN exposure resulted in varying degrees of inhibition of antioxidant enzymes, induction of lipid peroxidation, and alterations of biochemical parameters of serum. CTX and/or AA pre-treatment provided near complete protection in terms of serum and tissues' biochemical changes, antioxidant enzymes activity and oxidative stress, especially when given in combination.

Acknowledgments The authors would like to thank SandozNovartis, Egypt, for supplying Ceftriaxone ${ }^{\circledR}$ used in our experiment. The company had neither role in designing the experiment nor in publication process. This research received no Grant from any funding agency.

Conflict of interest The authors declare that there are no conflicts of interest.

\section{References}

Abdel-Daim MM (2014) Pharmacodynamic interaction of Spirulina platensis with erythromycin in Egyptian Baladi bucks (Capra hircus). Small Rumin Res 120:234-241. doi:10.1016/j.smallrumres.2014.05.013

Abdel-Daim M, Halawa S (2014) Synergistic hepatocardioprotective and antioxidant effects of myrrh and ascorbic acid against diazinon-induced toxicity in rabbits. Int Res $\mathbf{J}$ Humanit Eng Pharm Sci 1:1-7

Abdel-Daim M, Funasaka Y, Kamo T, Ooe M, Matsunaka H, Yanagita E, Itoh T, Nishigori C (2010a) Effect of chemical peeling on photocarcinogenesis. J Dermatol 37:864-872. doi:10.1111/j.1346-8138.2010.00859.x

Abdel-Daim M, Funasaka Y, Kamo T, Ooe M, Matsunaka H, Yanagita E, Itoh T, Nishigori C (2010b) Preventive effect of chemical peeling on ultraviolet induced skin tumor formation. J Dermatol Sci 60:21-28. doi:10.1016/j. jdermsci.2010.08.002

Abdel-Daim M, Abuzead S, Halawa S (2013) Protective role of Spirulina platensis against acute deltamethrin-induced toxicity in rats. PLoS ONE 8:e72991

Abdel-Daim MM, Abd Eldaim MA, Mahmoud MM (2014) Trigonella foenum-graecum protection against deltamethrin-induced toxic effects on haematological, biochemical, and oxidative stress parameters in rats. Can $\mathrm{J}$ Physiol Pharmacol 1-7. doi:10.1139/cjpp-2014-0144

Aebi H (1984) Catalase in vitro. Methods Enzymol 105:121-126

Akash MS, Shen Q, Rehman K, Chen S (2012) Interleukin-1 receptor antagonist: a new therapy for type 2 diabetes mellitus. J Pharm Sci 101:1647-1658. doi:10.1002/jps. 23057

Akash MS, Rehman K, Chen S (2013) Role of inflammatory mechanisms in pathogenesis of type 2 diabetes mellitus. J Cell Biochem 114:525-531. doi:10.1002/jcb.24402

Al-Attar AM, Abu Zeid IM (2013) Effect of tea (Camellia sinensis) and olive (Olea europaea L.) leaves extracts on male mice exposed to diazinon. Biomed Res Int 461415. doi: $10.1155 / 2013 / 461415$

Al-Sayed E, Martiskainen O, Seif El-Din SH, Sabra AN, Hammam OA, El-Lakkany NM, Abdel-Daim MM (2014) Hepatoprotective and antioxidant effect of Bauhinia hookeri extract against carbon tetrachloride-induced hepatotoxicity in mice and characterization of its bioactive compounds by HPLC-PDA-ESI-MS/MS. Biomed Res Int 2014:245171. doi:10.1155/2014/245171

Amin B, Hajhashemi V, Hosseinzadeh H, Abnous K (2012) Antinociceptive evaluation of ceftriaxone and minocycline alone and in combination in a neuropathic pain model in rat. Neuroscience 224:15-25. doi:10.1016/j.neuroscience. 2012.07.058

Ashrafi F, Nematbakhsh M, Safari T, Talebi A, Nasri H, Khazaei M, Baradaran-Mahdavi MM, Jafapisheh A, Olia B, Pirhaji O, Hashemi-Nia SJ, Eshraghi F, Pezeshki Z, Mortazavi M (2012) A combination of vitamin C and losartan for cisplatin-induced nephrotoxicity in rats. Iran J Kidney Dis 6:361-365

Azab S, Abdel-Daim M, Eldahshan O (2013) Phytochemical, cytotoxic, hepatoprotective and antioxidant properties of Delonix regialeaves extract. Med Chem Res 22:4269-4277

Beauchamp D, Theriault G, Grenier L, Gourde P, Perron S, Bergeron Y, Fontaine L, Bergeron MG (1994) Ceftriaxone protects against tobramycin nephrotoxicity. Antimicrob Agents Chemother 38:750-756 
Beutler E, Duron O, Kelly BM (1963) Improved method for the determination of blood glutathione. J Lab Clin Med 61:882-888

Boroushaki MT, Arshadi D, Jalili-Rasti H, Asadpour E, Hosseini A (2013) Protective effect of pomegranate seed oil against acute toxicity of diazinon in rat kidney. Iran $\mathbf{J}$ Pharm Res 12:821-827

Cakici O, Akat E (2013) Effects of oral exposure to diazinon on mice liver and kidney tissues: biometric analyses of histopathologic changes. Anal Quant Cytol Histol 35:7-16

Carr AC, Frei B (1999) Toward a new recommended dietary allowance for vitamin $\mathrm{C}$ based on antioxidant and health effects in humans. Am J Clin Nutr 69:1086-1107

Coulombe JJ, Favreau L (1963) A new simple semimicro method for colorimetric determination of urea. Clin Chem 9:102-108

Dwivedi VK, Bhatanagar A, Chaudhary M (2012) Protective role of ceftriaxone plus sulbactam with VRP1034 on oxidative stress, hematological and enzymatic parameters in cadmium toxicity induced rat model. Interdiscip Toxicol 5:192-200. doi:10.2478/v10102-012-0032-3

Eldahshan OA, Abdel-Daim MM (2014) Phytochemical study, cytotoxic, analgesic, antipyretic and anti-inflammatory activities of Strychnos nux-vomica. Cytotechnology. doi:10.1007/s10616-014-9723-2

El-Demerdash FM, Nasr HM (2013) Antioxidant effect of selenium on lipid peroxidation, hyperlipidemia and biochemical parameters in rats exposed to diazinon. $\mathrm{J}$ Trace Elem Med Biol 28:89-93. doi:10.1016/j.jtemb.2013.10. 001

El-Demerdash FM, Yousef MI, Zoheir MA (2005) Stannous chloride induces alterations in enzyme activities, lipid peroxidation and histopathology in male rabbit: antioxidant role of vitamin C. Food Chem Toxicol 43:1743-1752. doi:10.1016/j.fct.2005.05.017

Ellman GL, Courtney KD, Andres V Jr, Feather-Stone RM (1961) A new and rapid colorimetric determination of acetylcholinesterase activity. Biochem Pharmacol 7:88-95

ElMazoudy RH, Attia AA (2012) Endocrine-disrupting and cytotoxic potential of anticholinesterase insecticide, diazinon in reproductive toxicity of male mice. J Hazard Mater 209-210:111-120. doi:10.1016/j.jhazmat.2011.12.073

Elmazoudy RH, Attia AA, Abdelgawad HS (2011) Evaluation of developmental toxicity induced by anticholinesterase insecticide, diazinon in female rats. Birth Defects Res B Dev Reprod Toxicol 92:534-542. doi:10.1002/bdrb.20322

Funasaka Y, Abdel-Daim M, Kawana S, Nishigori C (2012) Effect of chemical peeling on the skin in relation to UV irradiation. Exp Dermatol 21:31-35. doi:10.1111/j.16000625.2012.01500.x

Green LC, Wagner DA, Glogowski J, Skipper PL, Wishnok JS, Tannenbaum SR (1982) Analysis of nitrate, nitrite, and $[15 \mathrm{~N}]$ nitrate in biological fluids. Anal Biochem 126: $131-138$

Gunduz O, Oltulu C, Buldum D, Guven R, Ulugol A (2011) Anti-allodynic and anti-hyperalgesic effects of ceftriaxone in streptozocin-induced diabetic rats. Neurosci Lett 491:23-25. doi:10.1016/j.neulet.2010.12.063

Hariri AT, Moallem SA, Mahmoudi M, Memar B, Hosseinzadeh H (2010) Sub-acute effects of diazinon on biochemical indices and specific biomarkers in rats: protective effects of crocin and safranal. Food Chem Toxicol 48:2803-2808. doi:10.1016/j.fct.2010.07.010

Ibrahim A, Abdel Daim M (2015) Modulating effects of Spirulina platensis against tilmicosin-induced cardiotoxicity in mice. Cell $\mathrm{J} 17$ (in press)

Kojo S (2004) Vitamin C: basic metabolism and its function as an index of oxidative stress. Curr Med Chem 11:10411064

Koracevic D, Koracevic G, Djordjevic V, Andrejevic S, Cosic V (2001) Method for the measurement of antioxidant activity in human fluids. J Clin Pathol 54:356-361

Larkin DJ, Tjeerdema RS (2000) Fate and effects of diazinon. Rev Environ Contam Toxicol 166:49-82

Larsen K (1972) Creatinine assay in the presence of protein with LKB 8600 reaction rate analyser. Clin Chim Acta 38: $475-476$

Li SH, Ryu JH, Park SE, Cho YS, Park JW, Lee WJ, Chun YS (2010) Vitamin C supplementation prevents testosteroneinduced hyperplasia of rat prostate by down-regulating HIF-1alpha. J Nutr Biochem 21:801-808. doi:10.1016/j. jnutbio.2009.06.004

Liu C, Cao F, Tang QZ, Yan L, Dong YG, Zhu LH, Wang L, Bian ZY, Li H (2010) Allicin protects against cardiac hypertrophy and fibrosis via attenuating reactive oxygen species-dependent signaling pathways. J Nutr Biochem 21:1238-1250. doi:10.1016/j.jnutbio.2009.11.001

Madkour F, Abdel-Daim M (2013) Hepatoprotective and antioxidant activity of dunaliella salina in paracetamolinduced acute toxicity in rats. Indian J Pharm Sci 75: 642-648

Mihara M, Uchiyama M (1978) Determination of malonaldehyde precursor in tissues by thiobarbituric acid test. Anal Biochem 86:271-278

Nematbakhsh M, Pezeshki Z, Eshraghi-Jazi F, Ashrafi F, Nasri H, Talebi A, Safari T, Haghighi M, Mansouri A (2012) Vitamin E, vitamin C, or losartan is not nephroprotectant against cisplatin-induced nephrotoxicity in presence of estrogen in ovariectomized rat model. Int $\mathbf{J}$ Nephrol 2012:284896. doi:10.1155/2012/284896

Neu HC (1985) Relation of structural properties of beta-lactam antibiotics to antibacterial activity. Am J Med 79:2-13

Neu HC, Meropol NJ, Fu KP (1981) Antibacterial activity of ceftriaxone (Ro 13-9904), a beta-lactamase-stable cephalosporin. Antimicrob Agents Chemother 19:414-423

Nishikimi M, Appaji N, Yagi K (1972) The occurrence of superoxide anion in the reaction of reduced phenazine methosulfate and molecular oxygen. Biochem Biophys Res Commun 46:849-854

Paglia DE, Valentine WN (1967) Studies on the quantitative and qualitative characterization of erythrocyte glutathione peroxidase. J Lab Clin Med 70:158-169

Ranjbar A, Pasalar P, Abdollahi M (2002) Induction of oxidative stress and acetylcholinesterase inhibition in organophosphorous pesticide manufacturing workers. Hum Exp Toxicol 21:179-182

Rawls SM, Baron DA, Kim J (2010a) beta-Lactam antibiotic inhibits development of morphine physical dependence in rats. Behav Pharmacol 21:161-164. doi:10.1097/FBP. 0b013e328337be10

Rawls SM, Zielinski M, Patel H, Sacavage S, Baron DA, Patel D (2010b) Beta-lactam antibiotic reduces morphine analgesic 
tolerance in rats through GLT-1 transporter activation. Drug Alcohol Depend 107:261-263. doi:10.1016/j. drugalcdep.2009.10.010

Razavi BM, Hosseinzadeh H, Movassaghi AR, Imenshahidi M, Abnous K (2013) Protective effect of crocin on diazinon induced cardiotoxicity in rats in subchronic exposure. Chem Biol Interact 203:547-555. doi:10.1016/j.cbi.2013. 03.010

Rehman K, Akash MS, Azhar S, Khan SA, Abid R, Waseem A, Murtaza G, Sherazi TA (2012) A biochemical and histopathologic study showing protection and treatment of gentamicin-induced nephrotoxicity in rabbits using vitamin C. Afr J Tradit Complement Altern Med 9:360-365

Saleem U, Ahmad B, Rehman K, Mahmood S, Alam M, Erum A (2012) Nephro-protective effect of vitamin C and Nigella sativa oil on gentamicin associated nephrotoxicity in rabbits. Pak J Pharm Sci 25:727-730

Salem H, Olajos EJ (1988) Review of pesticides: chemistry, uses and toxicology. Toxicol Ind Health 4:291-321

Sams C, Cocker J, Lennard MS (2004) Biotransformation of chlorpyrifos and diazinon by human liver microsomes and recombinant human cytochrome P450s (CYP). Xenobiotica 34:861-873. doi:10.1080/00498250400017273

Sun Y (1990) Free radicals, antioxidant enzymes, and carcinogenesis. Free Radic Biol Med 8:583-599
Tsitsimpikou C, Tzatzarakis M, Fragkiadaki P, Kovatsi L, Stivaktakis P, Kalogeraki A, Kouretas D, Tsatsakis AM (2013) Histopathological lesions, oxidative stress and genotoxic effects in liver and kidneys following long term exposure of rabbits to diazinon and propoxur. Toxicology 307:109-114. doi:10.1016/j.tox.2012.11.002

Whitehead TP, Bevan EA, Miano L, Leonardi A (1991) Defects in diagnostic kits for determination of urate in serum. Clin Chem 37:879-881

Willcox JK, Ash SL, Catignani GL (2004) Antioxidants and prevention of chronic disease. Crit Rev Food Sci Nutr 44:275-295. doi:10.1080/10408690490468489

Yilmaz N, Ilhan S, Naziroglu M, Oktar S, Nacar A, Arica V, Tutanc M (2011) Ceftriaxone ameliorates cyclosporine A-induced oxidative nephrotoxicity in rat. Cell Biochem Funct 29:102-107. doi:10.1002/cbf.1727

Yoshiyama Y, Yazaki T, Beauchamp D, Kanke M (1998) Protective effect of ceftriaxone against the nephrotoxicity of isepamicin administered once daily in rats. Biol Pharm Bull 21:520-523

Zavon MR (1971) Treatment of organophosphorus and chlorinated hydrocarbon insecticide intoxications. Mod Treat $8: 503-510$ 